\title{
URGENSI PEMBENTUKAN MODEL PEMBINAAN DAN PEMBIMBINGAN BERBASIS KOMPETENSI BAGI NARAPIDANA PELAKU CYBERCRIME
}

\author{
Widodo \\ Wiwik Utami \\ Nukhan Wicaksono Pribadi \\ Fakultas Hukum Universitas Wisnuwardhana Malang \\ J1. Danau Sentani 99 Malang \\ Email: widodoguru@yahoo.co.id
}

\begin{abstract}
The judge imprison all cybercrime convicts in Indonesia to be trained in house of correction. Nonetheles, the application of training model for inmate in house of correction.(Lembaga Pemasyarakatan/LAPAS) or even mentoring model for inmate in correctional center (Balai Pemasyarakatan/BAPAS) has not used the principles of modern penology. This fact causes the purpose of imprisonment the convicts cannot be obtained optimally. One of the evidences is the inmates repeating their crimes (residive). Therefore, it is necessary to develop new model based on modern penology for training and mentoring the inmates. The purpose of this research is finding out the urgency and the specification of new model training. The achievement of goals is conducted using research techniques development in LAPAS and BAPAS on territory East Java and D.I Yogyakarta. The new model is called as Training and Competency-Based Mentoring for cybercrime convict. The reason of the urgency this new model is the inmates individually have a potential in the field of Information and Communication Technology. They also want to get more value in LAPAS. Now, there is no law governing the specific training for cybercrime inmates. Therefore, it is necessary to develop a new model of training the inmate based on rational and scientific approaching. While, the specification of the model and the construction of the model is based on the inmates' need and what they need to get job in accordance with 9 competency of information and technology experts, as well as in accordance with visionary modern penology.
\end{abstract}

Key words: model, inmate, cybercrime, competency, penology

\begin{abstract}
Abstrak
Hakim menjatuhkan pidana penjara terhadap semua pelaku tindak pidana cybercrime di Indonesia, dan dibina di Lembaga Pemasyarakatan (LAPAS). Namun, model pembinaan di narapidana di LAPAS dan pembimbingan narapidana di BAPAS belum menggunakan prinsipprinsip penologi modern, sehingga tujuan pemidanaannya belum tercapai secara optimal. Salah satu buktinya, banyak narapidana yang mengulangi kejahatannya (residive). Karena itu, perlu konstruksi model baru pembinaan yang sesuai dengan prinsip penologi modern. Tujuan penelitian ini untuk menemukan urgensinya dan spesifikasi model pembinanan. Pencapaian tujuan dilakukan dengan menggunakan teknik penelitian pengembangan di LAPAS dan BAPAS pada wilayah Jawa Timur dan Daerah Istimewa Yogyakarta. Model temuan disebut pembinaan dan pembimbingan narapidana cybercrime berbasis kompetensi. Urgensi penemuan model ini
\end{abstract}


karena secara individual narapidana mempunyai potensi dalam bidang Teknologi Informasi dan Komunikasi (TIK), mereka ingin mendapat "nilai tambah" dalam LAPAS, belum ada ketentuan hukum yang mengatur pembinaan khusus pada terpidana cybercrime, perlu pembinaan narapidana yang didasarkan pada pendekatan-pendekatan yang rasional dan ilmiah. Sedangkan spesifikasi dan konstruksi modelnya didasarkan pada kebutuhan narapidana dan kompetensi yang dibutuhkan di lapangan kerja, sesuai dengan standar kompetensi pemasyarakatan dan standar kompetensi 9 bidang kompetensi ahli teknologi informasi, serta sesuai dengan visi penologi modern.

Kata kunci: model, narapidana, cybercrime, kompetensi, penologi

\section{Latar Belakang}

Kejahatan dalam bidang teknologi informasi (cybercrime) adalah kejahatan yang menggunakan komputer sebagai sasaran kejahatan, dan kejahatan yang menggunakan komputer sebagai sarana melakukan kejahatan. Kejahatan ini adalah kejahatan dalam pengertian yuridis, yaitu tindak pidana yang diatur dalam peraturan perundangundangan. ${ }^{1}$

Cybercrime terjadi di kawasan perkotaan sampai perdesaan, yang merupakan dampak negatif dari perkembangan teknologi informasi dan komunikasi. Karakteristik pelakunya berbeda dengan pelaku kejahatan konvensional, antara lain: terdidik, menguasai aplikasi TIK, tidak selalu bermotif ekonomi, kreatif dan ulet. $^{2}$ Semua terpidana dibina di Lembaga Pemasyarakatan (LAPAS) dan dibimbing di Balai Pemasyarakatan (BAPAS). ${ }^{3}$

Secara umum prinsip pemasyarakatan di Indonesia sudah memuat pendekatan penologi modern, tetapi belum semuanya diterapkan. Berdasarkan fakta, pelaku cybercrime di LAPAS dibina dan dibimbing dengan materi, metode, dalam waktu bersamaan dan bercampur dengan penjahat jalanan (misalnya pemerkosa, pembunuh, pencuri), padahal karakteristik mereka berbeda. ${ }^{4}$ Akibatnya, ada narapidana yang menjadi residivis, ${ }^{5}$ misalnya, dalam kasus penipuan, perjudian. Dalam perspektif penologi, Rajendra Kumar Sharma mengemukakan bahwa dalam penologi, pidana penjara merupakan sarana re-edukasi, resosialisasi, rehabilitasi, dan reformasi

1 Widodo, Hukum Pidana di Bidang Teknologi Informasi, Aswaja Pressindo, Yogyakarta, 2013, hlm. 5.

2 Widodo, Analisis Kriminologis tentang Penyebab Pelaku Kejahatan yang Berhubungan dengan Komputer di Indonesia (Studi di Unit V Infotek/Cybercrime, Direktorat II Markas Besar Kepolisian Negara Republik Indonesia, Jurnal Ilmiah Hukum dan Dinamika Masyarakat, Fakultas Hukum Universitas Tujuh belas Agustus Semarang, ISSN:0854-2031, TERAKREDITASI SK Dirjen Dikti No.55A/DIKTI/ KEP/2006, Volume 4 No. 2, April 2007.

3 Widodo, Pidana Kerja Sosial dan Pidana Pengawasan sebagai Alternatif Pengganti Pidana Penjara bagi Pelaku Tindak Pidana Cybercrime (Studi di Daerah Hukum Pengadilan Tinggi Yogyakarta), Laporan Akhir Hasil Penelitian Fundamental, 2009, hlm. 98.

4 Ibid.

5 Widodo dan Wiwik Utami, Pidana Kerja Sosial dan Pidana Pengawasan sebagai Alternatif Pengganti Pidana Penjara bagi Pelaku Tindak Pidana Cybercrime (Studi di Daerah Hukum Pengadilan Tinggi Yogyakarta), Laporan Penelitian Fundnamental, 2008, hlm. 46. 
narapidana ${ }^{6}$ dan harus dilaksanakan untuk menghindari residivisme.

Di Indonesia belum ada model pembinaan yangterukurdanteruji untuk pelaku cybercrime agar terhindar dari residivisme. Perlu ada konstruksi model baru untuk pembinaan dengan cara membentuk pembinaan berbasis kompetensi. Dalam konteks ini, kompetensi diartikan sebagai seperangkat tindakan cerdas, penuh tanggungjawab yang dimiliki seseorang sebagai syarat untuk dianggap mampu oleh masyarakat dalam melaksanakan tugas-tugas di bidang pekerjaan tertentu. ${ }^{7}$ Jika pembinaan dan pembimbingan narapidana pelaku cybercrime tidak efektif sebagaimana saat ini, jumlah kejahatan cybercrime di Indonesia makin meningkat dan masyarakat yang menanggung kerugian baik material maupun nonmaterial.

Mengingat perlunya penemuan model baru tersebut, penulis berinisiatif mengkonstruksi model pembinaan berbasis kompetensi mantan narapidana. Model pembinaan dan pembimbingan narapidana berbasis kompetensi adalah abstraksi proses dan susbtansi pembinaan dan pembimbingan yang berwujud deskripsi kognitif tentang model pembinaan dan pembimbingan yang bersifat aplikatif yang disusun berdasarkan standar kompetensi yang harus dimiliki mantan narapidana.
Model pembinaan tersebut harus disusun berdasarkan kebutuhan narapidana setelah selesai menjalani pidana, baik berupa softskill maupun hardskill. Dasar penyusunan model pembinaan harus didasarkan pada hasil penelitian empiris di LAPAS dan BAPAS, sehingga permasalahan yang muncul adalah apakah urgensi penyusunan model pembinaan narapidana cybercrime dan bagaimana spesifikasi dan konstruksi model pembinaan yang sesuai dengan pendekatan penologi modern agar tidak terjadi residivisme. Untuk memenuhi kebutuhan tersebut, penulis mengadakan penelitian pada beberapa LAPAS dan BAPAS di wilayah Jawa Timur dan Daerah Yogyakarta. Di wilayah tersebut banyak terjadi kasus cybercrime. Hasil penelitian dapat dimanfaatkan oleh Direktorat Jenderal Pemasyarakatan Kemanterian Hukum dan Hak Asasi Manusia untuk bahan utama penyusunan model pembinaan terpidana cybercrime di LAPAS dan BAPAS. Penulisan jurnal ini didasarkan pada penelitian hukum empiris empiris, atau biasa disebut penelitian hukum nondoktrinal. ${ }^{8}$ Berdasarkan tujuan yang ingin dicapai, penelitian ini tergolong dalam penelitian pengembangan (Research and Development). Borg dan Gall berpendapat bahwa pengertian penelitian dan pengembangan adalah proses

6 Rajendra Kumar Sharma, Criminology and Penology, Atlantics Publishers and Distributors, Delhi, 1998, hlm. 3 .

7 Keputusan Menteri Pendidikan Nasional Republik Indonesia Nomor 045/U/2002 tentang Kurikulum Inti Pendidikan Tinggi.

8 Soetandyo Wignjosoebroto, Hukum dan Metode-metode Kajiannya, Makalah, 2001, hlm. 4. 
pengembangan dan validasi produk dalam bidang pendidikan melalui siklus tertentu. ${ }^{9}$

Penelitian ini dilakukan di LAPAS Kelas I Surabaya di Porong, LAPAS Kelas I Malang, LAPAS Kelas II Wirogunan Yogyakarta, dan LAPAS Kelas II Jember. Penentuan BAPAS akan diketahui dari LAPAS berdasarkan data tentang penempatan narapidana pasca pemidanaan di LAPAS, yaitu di BAPAS Surabaya dan BAPAS Yogyakarta, karena berdasarkan pendapat Roy Suryo lima kota besar yang banyak terjadi cybercrime adalah Yogyakarta, Jakarta, Surabaya, Malang dan Bandung. ${ }^{10}$

Pengumpulan bahan hukum dan data dilakukanmelaluistudidokumen(documentary research) dan studi lapangan (field research). Studi dokumen akan memberikan gambaran tentang hasil analisis ketentuan hukum yang digunakan oleh pembina pemasyarakatan di LAPAS dalam membina pelaku cybercrime di dalam maupun luar LAPAS. Sedangkan studi lapangan dilakukan untuk mengetahui pelaksanaan pembinaan dan pembimbingan narapidana beserta hal-hal yang terkait dengan pembinaan dan pembimbingan narapidana. Responden dalam penelitian ini ditentukan secara bertujuan (purposive) berdasarkan kualifikasi yang sudah ditentukan peneliti, begitu juga para ahli yang akan dilibatkan uji ahli atas model.

Analisis beberapa dokumen hukum tersebut digunakan sebagai salah satu bahan penunjang analisis data agar hasilnya bersifat komprehensif untuk membentuk generalisasi. ${ }^{11}$ Sedangkan untuk menganalisis data sekunder digunakan sistem SQ-3 R, yakni survey, question, read, recite/recall, review. ${ }^{12}$ Data lengkap yang diperoleh melalui teknik wawancara, observasi dan studi dokumentasi tersebut kemudian dianalisis secara kualitatif cara menguraikan secara deskriptif-analitis dan preskriptif. Dalam melakukan analisis kualitatif yang bersifat deskriptif dan preskriptif ini, analisis bertitik tolak pada analisis yuridis-sistematis yang dilengkapi dengan analisis empiris serta analisis komparatif. ${ }^{13}$

Residivis disebabkan oleh banyak faktor, antara lain proses kegiatan pembinaan di LAPAS, konsisi psikologis, dan psikologi sosial, serta lingkungan narapidana. ${ }^{14}$ Karena itu, narapidana perlu dibina secara serius dan diperlakukan sebagai orang yang tersesat oleh LAPAS sesuai dengan konsep pemasyarakatan yang dikemukakan oleh

9 Walter R. Borg, and Meredith Damien Gall, Educational Research: An Introduction, Fifth Edition, Longman, New York, 1989, hlm. 32.

10 R.M. Roy Suryo, Kejahatan Cyber Marak di Indonesia, Suara Pembaruan, 11 Juli 2000, hlm. 12.

11 Koenjtaraningrat, Metode Penelitian Ilmu Sosial, Gramedia, Jakarta, 1981. hal. 65.

12 Sri Mamudji, Teknik Menganalisa Dokumen, Makalah dalam Penataran Metode Penelitian Hukum di Jakarta, 21-31 Juli 1997.

13 Sunaryati Hartono, Penelitian Hukum Menjelang Abad XXI, Alumni, Bandung, 1984, hlm. 38.

14 Hamaria Mendrofa Simatupang, dan Irmawati, Dinamika Faktor-faktor Psikososial pada Residivis Remaja Pria (Studi Kasus Residivis Remaja Pria di LAPAS Anak Tanjung Gusta Medan), Program Studi Psikologi Fakultas Kedokteran Universitas Sumatra Utara. 
Sahardjo pada tahun 1963, bahwa narapidana harus dibina dan didik secara manusia, dan dikenalkan kembali kepada masyarakat dengan cara yang manusiawi agar tidak mengulangi kejahatannya kembali. ${ }^{15}$ Hal ini selaras dengan paradigma penologi modern dan teori kriminologi positif, yang melahirkan Aliran modern (aliran positif) dalam hukum pidana dan akhirnya menemukan konsepsi individualisasi pemidanaan (individualization of sentencing) dan individualisasi pembinaan (individualization treatment). Aliran modern tersebut mengembangkan scientific justice secara lebih sistematis, karena studi tentang kejahatan dan penjahat dilandasi oleh pendekatan ilmiah dan pendekatan antardisiplin ilmu, khususnya dalam memahami pelaku tindak pidana (scientific treatment of the criminal). ${ }^{16}$

Pembinaan narapidana secara individual sangat sesuai dengan karakteristik narapidana cybercrime dan tujuan pemidanaan sebagaimana tertuang dalam UU Pemasyarakatan. Hal ini didasarkan pertimbangan bahwa terpidana cybercrime mempunyai karekter khusus yaitu: pandai, ulet, menguasai teknologi informasi, kalangan terpelajar yang perlu dibina secara khusus agar mampu berperan aktif dalam pembangunan, ${ }^{17}$ kemudian dibina dan dibimbing dengan cara yang khusus agar tidak menjadi residivis, melalui model pembinaan dan pembimbingan yang didasarkan pada kompetensi yang dibutuhkan mantan narapidana dan selaras dengan asas-asa penologi, kriminologi, dan sosiologi.

Proses pembinaan dan pembimbingan narapidana cybercrime wajib menggunakan pendekatan andragogis, yaitu ilmu dan seni mengajar orang dewasa. Namun karena orang dewasa sebagai individu yang sudah mandiri dan mampu mengarahkan dirinya sendiri, maka dalam andragogi yang terpenting dalam proses interaksi belajar adalah kegiatan belajar mandiri yang bertumpu kepada warga belajar (Learner Centered Training/Teaching). Metode pembelajarannya sebaiknya (1) berpusat pada pemasalahan peserta belajar, (2) menuntut dan mendorong peserta belajar untuk aktif dalam proses pembelajaran, (3) mendorong peserta untuk mengemukakan pengalaman sehari-harinya dalam proses pembelajaran, (4) menumbuhkan kerja sama, baik antara sesama peserta, dan antara peserta dengan tutor, dan (5) lebih bersifat pemberian pengalaman kepada peserta belajar, bukan

15 Made Sadhi Astuti, Pemidanaan terhadap Anak sebagai Pelaku Tindak Pidana, IKIP Malang, Malang, 1997, hlm. 46.

16 Muladi dan Barda Nawawi Arief, Kapita Selekta Hukum Pidana, Alumni, Bandung, 1992, hlm. 96.

17 Teguh Prasetyo, Hukum Pidana, Jakarta, Rajawali Pers, 2010, hlm. 121.

Azriadi, Pelaksanaan Pembinaan Narapidana Residivis Berdasarkan Prinsip Pemasyarakatan di Lembaga Pemasyarakatan Kelas II A Biaro (Tinjauan Mengenai Prinsip Pemasyarakatan Tentang Perlindungan Negara), Program Pascasarjana Ilmu Hukum Universitas Andalas Padang, 2011.

Hamaria Mendrofa Simatupang, dan Irmawati, Dinamika Faktor-faktor Psikososial pada Residivis Remaja Pria (Studi Kasus Residivis Remaja Pria di LAPAS Anak Tanjung Gusta Medan), Program Studi Psikologi Fakultas Kedokteran Universitas Sumatra Utara. 
merupakan transformasi atau penyerapan materi dari tutor kepada peserta belajar. ${ }^{18}$

Pendekatan andragogis terbukti dapat meningkatkan kualitas pembinaan dan pembimbingan narapidana di LAPAS, khususnya dalam pendidikan keagamaan (Islam). Pengembangan pendekatan ini memberikan dampak positif, baik terhadap fasilitator, narapidana, maupun lingkungan lembaga pemasyarakatan; dan menunjukkan adanya jaminan tentang kesinambungan (sustainability) model yang dikembangkan. Karena itu, penciptaan suasana pembelajaran yang kondusif, pelibatan warga belajar dalam pembelajaran (belajar partisipatif), proses pendidikan yang prospektif di LAPAS agar dapat membawa perubahan mental. ${ }^{19}$

Langkah-langkah penyusunan model pembinaan dan pembimbingan narapidana berbasis kompetensi adalah sebagai berikut

(a) Penetapan Profil Mantan Narapidana, (b) Perumusan Kompetensi Mantan Narapidana, (c) Pengkajian Kandungan Elemen Kompetensi Mantan Narapidana, (d) Pemilihan Bahan untuk Pemenuhan Standar Kompetensi Mantan Narapidana, (e) Pembentukan Pokok-pokok Materi Binaan Narapidana, dan (f) Penyusunan Model Pembinaan dan Pembimbingan Narapidana.
Berdasarkan konsepsi di atas maka desain model pembinanan narapidana berbasis kompetensi mantan narapidana untuk narapidana pelaku cybercrime di dalam LAPAS mempunyai sistematika berikut: (a) Rumusan Standar Kompetensi Mantan Narapidana Cybercrime; (b) Tujuan Pembinaan dan Pembimbingan Narapidana Berbasis Kompetensi Mantan Narapidana; (c) Indikator dan Deskriptor Keberhasilan Pembinaan dan Pembimbingan dalam Setiap Tahapan Pembinaan; (d) Metode Pembinaan dan Pembimbingan Narapidana Cybercrime Berdasarkan Pendekatan Penologi, Kriminologi, Sosiologi, dan Andragogi; (e) Standar Komptensi Pembimbing Pemasyarakatan di dalam LAPAS; (f) Materi Pembinaan dan Pembimbingan Narapidana Cybercrime di dalam LAPAS; (g) Sarana dan Prasarana Pembinaan dan Pembimbingan Narapidana Cybercrimedi dalam LAPAS; (h) Tahapan Pembinaan dan Pembimbingan Narapidana Berbasis Kompetensi Mantan Narapidana; dan (i) Langkah-Langkah Aplikasi, dan Alat Evaluasi Keberhasilan Pembinaan dan Pembimbingan Narapidana di dalam LAPAS.

Tahapan kegiatan pembinaan dan pembimbingan didasarkan pada hasil

18 Nur Shobah, Aplikasi Andragogi dalam Pembelajaran pendidikan Non Formal, Pemerhati Pendidikan Orang Dewasa dan Pamong Belajar BPKB Sulteng, http://kurtekdik06.blogspot.com, diakses 12 Desember 2010 pukul 08.00 WIB.

19 Mulyasa, Pengembangan Model Andragogi bagi Pembinaan dan pembimbingan Narapidana Perempuan di Lembaga Pemasyarakatan (Studi Terfokus pada Pendidikan Keagamaan (Islam) di Lembaga Pemasyarakatan Kelas IIA Bandung), Program Pascasarjana Universitas Pendidikan Indonesia (UPI), Bandung, 2005, hlm. 47. 
kesepakatan Badan Perserikatan Bangsa- Pada beberapa LAPAS bahkan belum pernah Bangsa yang menangani Pemberantasan Kejahatan di wilayah Asia Pasifik (UNAFEI), seperti pada uraian berikut:

1. Pre-Trial

a. The Village Justice System

b. Release on Recognizance and Other Diversion Services

2. Trial or Adjudication Stage

a. Suspended Sentence for Youth Offenders

1. Social Services:

2. Homelife Services

3. Educational Services

4. Psychological Services

5. Health Services

6. Economic Programs and Services in Rehabilitation Centers

7. Recreational Services

8. Developmental Services

b. Probation for Adult Offenders

3. Post-Trial Stage

a. Open Prison Programs

b. Pardon

c. Parole

4. Post-Institutionalization

a. Halfway House for Adult Prisoners

b. After Care Services. ${ }^{20}$

\section{Pembahasan}

Berdasarkan hasil penelitian diketahui bahwa di LAPAS Kelas I Surabaya, LAPAS Kelas I Malang, LAPAS Kelas II Jember, dan LAPAS Kelas II Yogyakarta, BAPAS Surabaya, BAPAS Malang, dan BAPAS Yogyakarta belum mempunyai peralatan atau sarana khusus yang dapat digunakan untuk membina keterampilan kerja yang menggunakan perangkat teknologi informasi. membina terpidana cybercrime. Di dalam LAPAS tersebut banyak narapidana yang tidak tergolong pelaku cybercrime, tetapi mempunyai bakat dan kemampuan dalam bidang teknologi informasi. Teknik, tempat, metode pembinaan keterampilan kerja dan pembimbingan rohani sama dengan yang disampaikan kepada pelaku tindak pidana katagori lainnya (misalnya: pencurian, penggelapan, korupsi, penganiayaan, pengeroyokan, pembunuhan, perzinahan). Di LAPAS Jember (yang saat ini membina terpidana cracking) dan LAPAS Yogyakarta (yang penah membina pelaku carding) juga belum melakukan pembinaan keterampilan kerjayang sesuaidenganbakat dan kemampuan narapidana. Semua kepala LAPAS dan BAPAS, penyebab belum dilakukannya pembinaan nerapidana cybercrime secara khusus adalah belum ada ketentuan hukum yang mengatur.

Sebagaimana pembinaan dan pembimbingan pada narapidana umumnya, pembinaan dan pembimbingan cybercrime dipengaruhi oleh faktor internal dan faktor eksternal LAPAS dan BAPAS. Faktor internal antara lain adalah keberadaan sarana dan prasarana, personalia, pembiaayaan, kemampuan menjalin kerjasama dengan pihak luar LAPAS dan BAPAS. Sedangkan faktor eksternal yang berpengaruh adalah narapidana dan mitra kerjasama. ${ }^{21}$ Selama ini pembinaan dan pembimbingan dilakukan sesuai dengan

20 Celia Copadocia Yangco, Community- Based Treatment For Offenders In The Philippines: Old Concepts, New Approaches, Best Practices, http://www.unafei.or., diakses 23 April 2011 pukul 02.30 WIB.

21 Wawancara dengan Harun Sulianto, Kepala LAPAS Kelas II Jember, Agustus dan September 2013. 
ketentuan hukum yang berlaku, termasuk pada pelaku cybercrime. Kerjasama juga dilakukan oleh berbagai pihak, namun khusus tentang kerjasama dengan pihak eksternal LAPAS diperlukan kordinasi dengan Kantor Wilayah Kementrarian Hukum dan Hak Asasi manusia (Kanwikemenkumham) di tingkat Provinsi. ${ }^{22}$

Setelah peneliti melakukan wawancara secara mendalam tentang konstruksi model pembinaan khusus pada pelaku cybercrime beserta rasionalitasnya, semua responden dalam penelitian ini, terdiri atas Kepala LAPAS Kelas II Jember, ${ }^{23}$ Kepala LAPAS Kelas II Wirogunan Yogyakarta, ${ }^{24}$ Kepala BAPAS Kelas I Surabaya, ${ }^{25}$ Kepala Seksi Pembimbingan (LAPAS Kelas I Surabaya, ${ }^{26}$ LAPAS Kelas II Yogyakarta, ${ }^{27}$ LAPAS Kelas II Jember, ${ }^{28}$ LAPAS Kelas I Malang ${ }^{29}$ ), kepala BAPAS kelas I Surabaya, Seksi Pembinaan Klien Anak BAPAS Kelas I Surabaya, ${ }^{30}$ memahami pemikiran penulis dan setuju jika ada model pembinaan terpidana cybercrime yang didasarkan pada kompetensi mantan narapidana. Mereka memahami bahwa palaku cybercrime adalah orangorang yang potensial untuk pengembangan pembangunan, sehingga perlu dibina agar tidak mengulangi kejahatannya serta dapat memanfaatkan kemampuannya dalam bidang teknologi informasi secara positif dalam rangka membangun bangsa.

Berdasarkan hasil wawancara dengan Wildan Yani Ashari (terpidana cracking situs Presiden Susilo Bambang Yudhoyono), diketahui bahwa berkaitan dengan bidang keterampilan kerja yang diperlukan, adalah dibina di LAPAS dan BAPAS sesuai dengan kemampuan serta bakatnya, dan juga sesuai dengan kebutuhan kompetensi tenaga kerja di masyarakat. Narapidana lainnya juga mengemukakan hal yang sama. Tujuannya, setelah keluar dari LAPAS akan memperoleh keterampilan baru dalam rangka hidup wajar di masyarakat dan memperoleh pekerjaan sesuai dengan bakat dan kemampuannya. Menurutnya, pembinaan mental dan kerohanian tetap lebih penting, agar dapat menyadari kesalahannya dan tidak mengulangi lagi. Meraka ingin dididik secara teknis oleh petugas pemasyarakatan yang kompeten dalam bidang teknologi informasi (khususnya bidang jaringan dan pengamanan sistem

22 Wawancara dengan Rudy Charles Gill, Kepala LAPAS Kelas II Yogyakarta, Agustus dan September 2013.

23 Wawancara dengan Harun Sulianto, Kepala LAPAS Kelas II Jember, Agustus dan September 2013.

24 Wawancara dengan Rudy Charles Gill, Kepala LAPAS Kelas II Yogyakarta, Agustus dan September 2013.

25 Wawancara dengan Pujo Harinto, Kepala BAPAS Kelas I Surabaya, Juli 2013.

26 Wawancara dengan Alfan, Kepala Sub-Seksi Pembimbingan Kemasyarakatan LAPAS Kelas I Surabaya di Porong, Agustus dan September 2013.

27 Wawancara dengan Heriyanto, Kepala Bidang Pembinaan Narapidana LAPAS Kelas II Yogyakarta, Agustus dan September 2013.

28 Wawancara dengan Alip Purnomo, Kepala Seksi Binadik LAPAS Kelas II A Jember, Agustus dan September 2013.

29 Wawancara dengan Karto Rahardjo, Kepala Bidang Pembinaan, September 2013.

30 Wawancara dengan Tri Pudyo, Pembimbing Kemasyarakatan (PK) BAPAS Kelas I Surabaya, Juni dan Juli 2013 
teknologi informasi). Kemampuan yang sudah dimiliki narapidana sudah cukup sebagai bekal awal mengembangkan kemampuan dalam bidang teknologi informasi, dan jika ditambah lagi dengan teknologi-teknologi terbaru maka akan lebih bermanfaat pada kehidupan di luar LAPAS. Karena itu, secara ideal diperlukan sarana dan prasarana serta instruktur yang dapat membina menuju pada keterampilan yang memadai. Namun karena fasilitas dan sumberdaya belum ada, maka kegiatankegiatannya dilakukan sesuai dengan jadwal dan tata tertib di LAPAS. ${ }^{31}$

Berdasarkan hasil wawancara, diketahui bahwa urgensi pembentukan model baru didasarkan fakta bahwa belum ada model khusus untuk pedoman pembinaan terpidana cybercrime. Secara individual narapidana mempunyai potensi yang bagus dalam bidang TIK dan memungkinkan untuk dikembangkan. Narapidana ingin mendapat nilai tambah dalam LAPAS dan BAPAS agar dapat bekerja dan tidak menjadi residivis. BAPAS dan LAPAS tidak melaksanakan pembinaan secara khusus karena belum ada ketentuan hukum yang mengatur pembinaan khusus. Secara penologis, perlu pembinaan dan pembimbingan narapidana yang didasarkan pada pendekatan-pendekatan yang rasional dan ilmiah. Mengingat belum ada model, maka yang digunakan oleh LAPAS dan BAPAS adalah model pembinaan yang bersifat umum. Akibatnya, banyak terpidana cybercrime yang tidak memperoleh nilai tambah sehingga menjadi residivis. Hal ini disebabkan oleh ketidaksesuaian antara keinginan narapidana dan standar kompetensi yang dibutuhkan di lapangan kerja dengan proses pembinaan dilaksanakan di LAPAS dan BAPAS. Hasil penelitian ini selaras dengan konsep penologi baru bahwa pembinaan pada terpidana penjara harus sesuai dengan konsep "klinik" dan "asas induvidualisasi pembinaan". Pembinaan harus sesuai dengan kebutuhan narapidana dan dilaksanakan secara kekhususan karakteristik narapidana. Melalui prinsip tersebut, narapidana akan dapat mengembangkan kemampuannya dalam rangka menjadikan narapidana lebih produktif.

Setelah penulis melakukan analisis berdasarkan kompetensi yang dibutuhkan oleh mantan rapidana, kesiapan dan kemampuan LAPAS dan BAPAS untuk membina dan membimbing terpidana cybercrime, maka spesifikasi dan konstruksi model pembinaan berbasis kompetensi adalah sebagai berikut.

\section{A. Pilihan Bidang Keahlian Mantan Narapidana}

Berdasarkan Peraturan Menteri Tenaga Kerja dan Transmigrasi, ada 9 bidang keahlian yang digunakan di Indonesia. Bidang keahlian dijadikan alternatif pilihan adalah bidang, yaitu: Operator Komputer, Programer Komputer, Jaringan Komputer dan Sistem Administrasi, Computer Technical

31 Wancara dengan Wildan Yani Ashari, Kepala Bidang Bimbingan Kemasyarakatan, Agustus 2013. 
Support, Multimedia, Teknisi Telekomunikasi Satelit, Keahlian Desain Grafis, Manajemen Layanan Teknologi Informasi, dan Keahlian Programmer Komputer. Berdasarkan hasil penelitian, ternyata bidang yang paling diminati oleh narapidana adalah operator komputer, programmer komputer, jaringan komputer dan sistem administrasi (termasuk pengamanan). Alasannya, ketiga bidang tersebut saat ini banyak dibutuhkan di masyarakat dan kemampuan teknis yang harus dipelajari tidak terlalu sulit.

Ketiga bidang tersebut bisa dilaksanakan dan dapat diajukan sertifikasi. Hal ini didasarkan pada ketentuan Peraturan Menteri Tenaga Kerja dan Transmigrasi Republik Indonesia Nomor 5 Tahun 2012 tentang Sistem Standardisasi Kompetensi Kerja Nasional maka Nama Standar Kompetensi Kerja Nasional Indonesia untuk Bidang Pekerjaan (sebagai penjabaran normatif dari Peraturan Presiden Nomor 8 Tahun 2012 tentang Kerangka Kualifikasi Nasional Indonesia), yang berkaitan dengan pembinaan narapidana cybercrime dalam LAPAS.

\section{B. Rumusan Standar Kompetensi Mantan Narapidana Cybercrime}

Standar Kompetensi Kerja Nasional Indonesia (SKKNI) adalah rumusan kemampuan kerja yang mencakup aspek pengetahuan, keterampilan dan atau keahlian serta sikap kerja yang relevan dengan pelaksanaan tugas dan persyaratan pekerjaan yang ditetapkan. SKKNI inilah yang menjadi pijakan dasar dalam penyusunan kompetensi narapidana cybercrime.
Pengertian kompetensi adalah kemampuan dan keahlian khusus yang wajib dimiliki oleh mantan narapidana cybercrime yang sudah selesai menjalankan pembinaan di LAPAS dan pembimbingan di BAPAS sesuai dengan kemampuan di bidang Tekologi Informasi dan perkembangan kebutuhan pasar tenaga kerja. Dengan demikian, dapat dipahami bahwa pengertian kompetensi kerja mantan narapidana cybercrime adalah kemampuan kerja setiap mantan narapidana yang mencakup aspek pengetahuan, keterampilan, dan sikap kerja yang sesuai dengan standar yang ditetapkan oleh pihak yang berwenang melalui sertifikasi.

Setelah dilakukan pengajian secara mendalam, ternyata ada 3 bidang kompetensi yang dapat dikembangkan di dalam LAPAS, yakni sebagai berikut.

a. Kompetensi Utama, yaitu narapidana menyadari kesalahannya, bermoral, berkomitmen untuk tidak mengulangi kesalahannya pada masa mendatang, dan mampu melakukan kegiatan produktif dalam masyarakat.

b. Kompetensi Pendukung, yaitu narapidana menguasai aplikasi teknis yang berkaitan dengan ilmu dan teknologi yang termasuk dalam rumpun 9 (sembilan) bidang keahlian.

c. Kompetensi Lainnya, yaitu soft skill yang dapat digunakan untuk melakukan berhubungan baik dengan sesama manusia.

Keterampilan lunak (soft skill) yang wajib dimiliki, yaitu: integritas tinggi, selalu 
berpikir secara logis dan analitis, mampu bekerja sama dalam tim, mempunyai motivasi tinggi untuk bekerja secara benar dan sah, mempunyai inisiatif tinggi, sikap pantang menyerah, mampu bekerjasama dengan kelompok, mampu bekerja di bawah tekanan, mempunyai keterampilan bergaul dengan orang lain, dapat beromunikasi secara verbal secara baik dan benar (mencakup keterampilan berkomunikasi, dan kemampuan berbahasa Inggeris), dan dapat beradaptasi dengan teknologi informasi terbaru.

\section{Tujuan Pembinaan dan Pembimbingan Narapidana Berbasis Kompetensi Mantan Narapidana}

Tujuan umum pembinaan dan pembimbingan narapidana cybercrime dengan model pembinaan berbasis kompetensi, yaitu: (a) mantan narapidana tidak mengulangi perbuatan pidananya, baik di dalam maupun di luar LAPAS; dan (b) mantan narapidana dapat aktif, produktif, dan berpartisipasi dalam pembangunan di masyarakat sesuai dengan bidang keahliannya.

Sedangkan tujuan khusus pembinaan dan pembimbingan narapidana cybercrime antara lain sebagai berikut: (a) menyadarkan narapidana bahwa perbuatan yang dilakukan (berupa kejatan yang melanggar ketentuan peraturan perundang-undangan) merugikan pihak lain secara ekonomis dan meresahkan masyarakat; (b) membebaskan narapidana dari rasa bersalah terpidana karena sudah dijatuhi pidana; (c) memberikan kesadaran dalam bidang keagamaan agar segera bertaubat (tidak mengulangi kejahataannya kembali; (d) memberikan bekal pengatahuan dan keterampilan kerja sesuai dengan bakat dan kemampuannya dalam operasionalisasi peralatan berbasisi teknologi informasi; dan (e) memberi bekal kemampuan sikap dan keterampilan lunak (soft skill) agar dapat bekerja secara profesional, jujur, dan bertanggungjawab.

\section{Indikator dan Deskriptor Keberhasilan Pembinaan dan Pembimbingan dalam Setiap Tahapan Pembinaan}

Indikator dan deskriptor keberhasilan pembinaan dan pembimbingan dalam setiap tahapan didasarkan dai hasil evaluasi proses kegengalihaiatan, dan hasil evaluasi dari hasil kegiatan. Evaluasi dilakukan oleh Tim Pengamat Pemasyarakatan (TPP). Evaluasi ini juga dilakukan dalam rangka pengalihan tahapan pembinaan. Karena secara normatif, pengalihan tahapan pembinaan dari satu tahap ke tahap lain ditetapkan melalui sidang Tim Pengamat Pemasyarakatan berdasarkan data dari Pembina Pemasyarakatan, Pengaman Pemasyarakatan Pembimbing Kemasyarakatan, dan Wali Narapidana. Adapun tahapan pembinaan narapidana dalam LAPAS terdiri atas dari atas 3 (tiga) tahap, sebagaimana diatur dalam Peraturan Pemerintah. 


\section{E. Metode Pembinaan dan}

\section{Pembimbingan}

Cybercrime

Narapidana

berdasarkan

Pendekatan Penologi, Kriminologi, Sosiologi, dan Andragogi

Metode pembinaan dan pembimbingan disesuaikan dengan materi. Namun secara umum matode yang mungkin dilaksanakan adalah: konseling, latihan terbimbing dan latihan mandiri. Sedangkan model pembelajaran dapat digunakan di LAPAS adalah: diskusi kelompok kecil (Small Group Discussion), Simulasi dan Demonstrasi, Pembelajaran Berkolaborasi (Collaborative Learning), serta Pembelajaran Berbasis Permasalahan (Problem-Based Learning). Semuamodelpembelajaran dapatdilaksanakan (termasuk bisa dimodifikasi sesuai dengan kebutuhan pembelajaran) tergantung pada tujuan pembelajaran dan luaran pembelajaran yang ditentukan dalam rencana pembelajaran dan silabus.

\section{F. Standar Komptensi Petugas Pemasyarakatan di dalam LAPAS dan Pembimbing Kemasyarakatan di BAPAS}

Petugas pemasyarakatan terdiri atas pembina kemasyarakatan dan pengaman pemasyarakatan. Semua pembina pemasyarakatan, pembimbimbing kemasyarakatan (baik dari kalangan internal LAPAS atau BAPAS) maupun dari luar LAPAS dan BAPAS, baik dalam kapasitasnya sebagai pembimbing bidang mental dan keagamaan, pembimbing latihan kerja (instruktur), wali narapidana, pembimbing kemasyarakatan wajib mempunyai kompetensi berikut.

a. Kompetensi Profesional, yaitu menguasai materi pembimbingan, baik ilmu pengetahuan, teknologi maupun seni sesuai dengan kapasitasnya.

b. Kompetensi Andragogi, yaitu mempunyai pengetahuan dan keterampilan menerapkan metode dalam pembimbingan, dan

c. Kompetensi integritas, yaitu memberikan contoh secara konkret melalui sikap tingkah laku nyata sebagaimana yang ia sampaikan (ada kesatuan antara ucapan dan tingkah lakunya).

G. Materi Pembinaan dan Pembimbingan Narapidana Cybercrime di dalam LAPAS dan BAPAS

Pembinaan dan pembimbingan bidang kepribadian narapidana meliputi hal-hal yang berkaitan dengan: (a) ketaqwaan kepada Tuhan Yang Maha Esa; (b) kesadaran berbangsa dan bernegara; (c) intelektual; (d) sikap dan perilaku; (e) kesehatan jasmani dan rohani; (f) kesadaran hukum; dan (g) reintegrasi sehat dengan masyarakat. Sedangkan pembinaan dan pembimbingan bidang kemandirian narapidana, meliputi hal-hal yang berkaitan dengan ketrampilan kerja dan latihan kerja dan produksi. Adapun materi pembinaan dan pembimbingan bidang kemandirian kerja disesuaikan dengan 9 bidang keahlian yang berhubungan dengan teknologi informasi 
sebagaimana diatur dalam Peraturan Menteri Tenaga Kerja dan Transmigrasi.

\section{H. Sarana dan Prasarana Pembinaan dan Pembimbingan Narapidana Cybercrime di dalam LAPAS dan BAPAS}

Sarana dan prasarana di LAPAS yang dibutuhkan adalah: (a) sarana dan prasarana pembinaan mental dan kerohanian; dan (b) sarana pelatihan kerja. Sarana dan prasarana dalam bidang mental dan kerohanian antara lain aula dan perabotnya, tempat ibadah dan perabotnya, ruang khusus dan perabotnya yang dapat digunakan untuk berkonsultasi narapidana secara individual. Sarana dan prasarana pembinaan keterampilan kerja adalah peralatan elektronik yang berbasis teknologi informasi dan komunikasi seuai dengan bidang kompetensinya masing-masing (misalnya komputer, jaringan terkoneksi, ruangan).

\section{Tahapan Pembinaan dan}

\section{Pembimbingan Narapidana \\ Berbasis Kompetensi Mantan Narapidana}

Tahapan pembinaan dan pembimbingan dilakukan dengan memenuhi persyaratan dan langkah berikut.

d. Sahap Sosialisasi Narapidana
Cybercrime. Tahapan ini berfungsi
memudahkan narapidana beradaptasi
pada lingkungan baru.

e. Tahap pemeriksaan fisis dan psikologis Narapidana Cybercrime. Tahap ini bermanfaat untuk mengetahui bakat, kemampuan, kecenderungan, motivasi, dan faktor psikis lain yang akan berpengaruh dalam proses pembinaan. Metode yang digunakan dalam tahap ini adalah sebagai berikut:

1. Wawancara dan observasi, yaitu sebagai metode paling dasar dan utama dalam investigasi psikologis dalam rangka melakukan intervensi.

2. Pemeriksaan Daftar Riwayat Hidup Narapidana,

3. Tes Psikologi untuk mengetahui motivasi, kecenderungan, bakat dan minat narapidana

4. Tahap Diagnosis tentang penyebab kejahatan dan prospek rehabilitasinya. Hal ini digunakan untuk menggambarkan karakteristik narapidana dan kelompok narapidana dalam rangka menyiapkan proses pembinaan dan pembimbingan termasuk konseling dan psikoterapi (jika diperlukan).

5. Tahap Pembinaan dan Pembimbingan, yang meliputi 2 bidang pembinaan dan pembimbingan bidang mental dan kepribadian, dan bidang kemandirian dan keterampilan kerja (sesuai ketentuan UU Pemasyarakatan). 


\section{J. Langkah-langkah Pelaksanaan, dan Alat Evaluasi Keberhasilan Pembinaan dan Pembimbingan Narapidana di dalam LAPAS dan BAPAS}

Pelaksanaan dilakukan sebagaimana proses pembelajaran orang dewasa yang meliputi perencanaan, persiapan pembelajaran, pelaksanaan pembelajaran, dan evaluasi. Evaluasi dilakukan oleh petugas yang berwenang baik dalam masa proses kegiatan (evaluasi proses) maupun hasil kegiatan (evaluasi hasil), yang terdiri atas evaluasi hasil kegiatan dan evaluasi hasil pembinaan dan pembimibngan. Proses pembinaan dilakukan oleh pembina pemasyarakatan atau petugas lain yang berwenang selama narapidana cybercrime dibina di dalam LAPAS. Sedangkan pembimbingan dilakukan oleh pembimbing kemasyarakatan atau petugas lain yang berwenang selama narapidana cybercrime dibimbing di BAPAS. Semua langkah tersebut dapat dilakukan dengan mengembangkan kerjasama LAPAS dengan pihak di luar LAPAS, baik sumberdaya manusia, laboratorium, maupun sertifikasi.

Ide tentang spesifikasi dan kosntruksi model pembinaan dan pembimbingan terhadap narapidana cybercrime berbasis kompetensi dapat dilaksanakan oleh pihak LAPAS dan BAPAS. Hal ini didasarkan pada rasionalitas berikut.

\section{Secara yuridis}

SetiapLAPASdanBAPASdapatmelakukan kerjasama dengan instansi pemerintah, swasta, organisaisi kemasyarakatan, dan bahkan perorangan. Hal ini secara sah diatur dalam Peraturan Pemerintah No. 57 Tahun 1999 tentang Kerja Sama Penyelenggaraan Pembinaan dan Pembimbingan Warga Binaan Pemasyarakatan.Dalam penjelasan Peraturan Pemerintah No. 31 Tahun 1999 diuraikan bahwa dalam rangka melaksanakan pembinaan dan pembimbingan, LAPAS dan BAPAS dapat melakukan kerjasama dengan instansi pemerintah terkait. Pengartian “instansi pemerintah terkait” adalah instansi pemerintah yang lingkup tugasnya meliputi bidang Agama, Pertanian, Pendidikan dan Kebudayaan, Sosial, Kesehatan, Tenaga Kerja, Perindustrian dan Perdagangan, Pemerintah Daerah, dan lain-lainnya. Yang dimaksud dengan "Badan-badan Kemasyarakatan lainnya" misalnya, yayasan, koperasi, dan lembaga swadaya masyarakat. Sedangkan yang dimaksud dengan perorangan adalah dokter, psikolog, pengusaha dan lainlainnya. Kerjasama tersebut termasuk dalam melakukan sertifikasi narapidana di bidang Teknologi Infomasi. Pada tahun 2013, Badan Penelitian dan Pengembangan Sumber Daya Manusia (Balitbang SDM), Kementerian Komunikasi dan Informatika, melalui Pusat Penelitian dan Pengembangan Literasi 
dan Profesi Kominfo bekerjasama dengan Lembaga Sertifikasi Profesi (LSP) TIK Indonesia menyelenggarakan ujian Sertifikasi Profesi sektor Teknologi Informasi dan Komunikasi. Sertifikasi tersebut dilaksanakan gratis beberapa kali, yaitu kali pertama di Balai Pelatihan dan Pengembangan Teknologi Informasi Komonikasi (BPPTIK) Cikarang, kedua di MMTC Yogyakarta, ketiga di Bandung dan setelah Surabaya akan dilaksanakan lagi di Bandung, terakhir di Pusat TIK Nasional Ciputat/Jakarta sebanyak 3 kali. Selama ini hanya lulusan SMK yang diberi peluang sertifikasi untuk mendaftar secara online melalui http://balitbang.kominfo.go.id. Jika LAPAS atau BAPAS menjalin kerjasama dengan Kemenkominfo, maka sertifikasi gratis terhadap narapidana cybercrime juga dapat dilakukan. ${ }^{32}$

\section{Secara empiris}

Pada beberapa LAPAS sudah melaksanakan kerjasama pelatihan kerja berbasis kompetensi, antara lain sebagai berikut

a. Pusat Pembinaan Kompetensi dan Pelatihan Konstruksi (Pusat Pembinaan KPK) Kementerian Pekerjaan Umum (PU) melakukan pelatihan konstruksi kepada narapidana di LAPAS Cipinang. Tujuannya adalah membentuk tenagatenaga terampil dan profesional di bidang jasa konstruksi menurut spesialisasi yang diminati oleh calon tenaga kerja, melalu pembinaan selama dua bulan. Program tersebut selaras dengan rencana strategis Kementerian PU yang memberdayakan Sumber Daya Manusia di bidang jasa konstruksi, khususnya kelompok kecil dan menengah. Pemberdayaan merupakan perwujudan peran serta Kementerian PU dalam bidang perekonomian untuk membantu masalah pengangguran. Program pelatihan tukang pemula di LAPAS Cipinang ini dijadikan proyek percontohan untuk mengisi formasi kerja di bidang jasa konstruksi di dalam negeri. ${ }^{33}$

b. Sebanyak 16 orang narapidana LAPAS Curup (Provinsi Bengkulu) mengikuti kegiatan Pelatihan Berbasis Kompetensi Las Listrik, melalui kerjasama LAPAS dengan Balai Latihan Kerja Provinsi Bengkulu. Melalui 2 orang instrukstur ahli, 16 warga binaan pemasyarakatan yang mengikuti pelatihan hingga tanggal 20 Juni 2013 tersebut diharapkan akan memiliki kompetensi las listrik yang memadai. ${ }^{34}$

\section{Secara teoretis (penologis)}

Secara teoretik, pembinaan dan pembimbingan yang dilaksanakan berdasarkan kopetensi yang dituju dengan

32 Balitbang SDM Kominfo Adakan Sertifikasi SDM TIK, https://www.kominfo.go.id, diakses 31 Juli 2013 pukul 13.30 WIB

33 Pusbin KPK Beri Pelatihan Tukang Kepada Narapidana, www.pu.go.id, diakses 31 Juli 2013 pukul 13.00 WIB. 34 http://lapascurup.com., diakses 30 Juli 2013 pukul 13.15 WIB. 
berbekal kemampuan dan keahlian yang dimiliki narapidana, akan menghasilkan keterampilan dan sikap yang lebih optimal. Hal ini dibuktikan dengan hasil penelitian, bahwa pelaksanaan pembinaan yang telah diprogramkan pada LAPAS Kelas I Semarang harus dilaksanakan sesuai dengan bidang ketrampilan yang ada serta didukung oleh sarana dan prasarana yang memadai, ${ }^{35}$ agar tujuan pemidanaan dapat tercapai.

Dalam perspektif penologi modern (penologi baru), ruang lingkup tema yang dipelajari dalam penologi bukan hanya pemidanaan di dalam lembaga khusus (pidana penjara), namun juga terkait dengan pembenaran dalam pemidanaan, teori-teori tentang pemenjaraan dan pemidanaan, sumber-sumber pengetahuan tentang pidana, perbandingan penologi, sejarah dan tujuan pidana penjara, kebijakan hukum pidana, adminisitrasi kepenjaraan dan penghuni penjara, sosiologi kepenjaraan, pertanggungjawaban dalam pemenjaraan, pembebasan bersyarat, pidana berbasis masyarakat, masa depan dan visi pemidanaan. Hal ini terungkap dalam pendapat berikut.

Core areas, running themes in penology: (a) Justifications of punishment, (b) Theorising about prisons and punishment; (c) Sources ofpenal knowlegde; (d) Comparative penologies; (e) The history and aims of imprisonment; (f) Penal policy; (g) Penal administration and prisioner populations; (h) Sociologies of prison life; (i) Penal accountability; (j) Probation and community penalties; and (k) Future directions and alternative visions. ${ }^{36}$

Berdasarkan hasil penelitian dan pemikiran dalam penologi modern, dapat dipahami bahwa kegiatan rehabilitasi dan resosialisasi hanya dapat dilaksanakan secara baik, yakni efisien dan efektif dalam mencapai tujuan, jika dilaksanakan berdasarkan konsep individualisasi pembinaan.Untuk melaksanakan program tersebut, proses rehabilitasi dan resosialisasi seyogyanya disesuaikan dengan kondisi fisik dan psikis narapidana berdasarkan suatu model yang disusun secara komprehensif (multi-disiplin ilmu) dari perpektif penologi modern, kriminologi, sosiologi dan andragogi. Karena itu, pendekatan multi-disiplin ilmu perlu dilakukan. Wujud konkretnya adalah pembinaan berbasis kompetensi mantan narapidana. Pembinaan berdasarkan asas individualisasi merupakan inti dari pembinaan berbasis kompetensi. Ini sejalan dengan pendapat bahwa dalam pembinaan diperlukan analisis yang mencakup tingkat kepentingan pembinaan dan pembimbingan, keterkaitan, permasalahan perilaku narapidana dan kemungkinan modikasi tingkah laku dan faktor-faktor penyebab kejahatan.

Individualized treatment program in behavior therapy is critical, 
complex, and strongly affected by pretreatment data obtained as part of a multimethod, multimodal assessment. The functional analysis is the integration of several elements for individualized treatment decision making: the relative importance, interrelationships, and sequelae of a client's behavior problems and treatment goals and the relative modifiability, interrelationships, and strength of causal variables. ${ }^{37}$

Ide pemulis tersebut sejalan dengan konsep bahwa upaya yang lebih rasional dari pengelola lembaga kepenjaraan terhadap kejahatan dan penyembuhan penjahat perlu penggunaan ilmu-ilmu "tingkah laku (bahavior sciences)" modern.

Finally, the sociologist insists that reformation must consist in preparing the convicted person for a normal type of socialized existence, and realizes that this can only be brought about by a system of social education during the period of incarceration and conditional release, and will only be obstructed by placing the individual in an environment widely different from that which exists in the daily life of the citizen. He realizes that any such procedure as solitary confinement or vindictive discipline will invariably result not in reformation, but in further deterioration of an already imperfectly developed personality. These are only a few of the more conspicuous aspects of the contribution of some of the phases of modern science to a more rational attitude towards crime and the treatment of the criminal. ${ }^{38}$

Bahkan sebagaimana muncul saat ini, penologi pos-modern membuat gagasan tentang bagaimana cara mengurangi kejahatan melalui program sosial yang luas, dan upaya rehabilitasi pelaku serta menekan pemicu kejahatan. Penologi pos-modern memang dapat diamati pada tingkat diskursif, namun langkah yang lebih penting adalah bagaimana implementasi kebijakan di tingkat lokal tersebut secara signifikan dapat melakukan re-orientasi pada tujuan program dengan citacita pengurangan kejahatan melalui upaya yang dilakukan oleh negara dalam kebijakankebijakan sosial dalam arti luas.

A postmodern penology abandons the idea of reducing crime through broad social programmes and rehabilitative efforts and is aimed at simply managing the harm that crime inflicts..., a postmodern penology may indeed be observable at the discursive level, policy implementation at the local level significantly complicates matters, reorienting programmatic goals to the ideal of crime reduction through expansive state efforts. ${ }^{39}$

37 Haynes, Stephen N.; Leisen, Mary Beth; Blaine, Daniel D., Design Of Individualized Behavioral Treatment Programs Using Functional Analytic Clinical Case Models, Psychological Assessment, Volume 9 (4), Dec 1997, hlm. 334.

38 Some Leading Phases of The Evolution of Modern Penology, archive.org/stream/jstor, diakses 12 Nopember 2013 pukul 08.00 WIB

39 Lisa L. Miller, Looking for Postmodernism in all the Wrong Places Implementing a New Penology, bjc. oxfordjournals.org., diakses 14 Nopember 2013 pukul 05.00 WIB. 


\section{Simpulan}

Urgensi penemuan model pembinaan dan pembimbingan berbasis kompetensi bagi narapidana pelaku cybercrime karena secara individual narapidana tersebut mempunyai kemampuan dan potensi dalam bidang TIK, mereka ingin mendapat nilai tambah dalam LAPASagardapatbekerjadantidakmengulangi tindak pidana (recidive), belum ada ketentuan hukum yang mengatur pembinaan khusus pada terpidana cybercrime, perlu ada pelaksanaan pembinaan yang didasarkan pada pendekatanpendekatan yang rasional dan ilmiah agar tujuan pemidanaan tercapai. Spesifikasi dan konstruksi modelnyadidasarkan pada kebutuhan narapidana dan kompetensi yang dibutuhkan di lapangan kerja, serta sesuai dengan visi penologi modern, yang pembentukannya diawali dengan penentuan kompetensi yang didasarkan pada 9 bidang kompetensi ahli teknologi informasi sampai dengan pelaksanaan evaluasi yang memenuhi persyaratan keilmuan agar peserta didik dapat memperoleh sertifikat profesi keahlian TIK dari pemerintah.

\section{DAFTAR PUSTAKA}

\section{Buku}

Made Sadhi Astuti, 1997, Pemidanaan Terhadap Anak Sebagai Pelaku Tindak Pidana, IKIP Malang, Malang. Muladi dan Barda Nawawi Arief, 1992, Kapita Selekta Hukum Pidana, Alumni, Bandung.

Rajendra Kumar Sharma, 1998, Criminology and Penology, Atlantics Publishers and Distributors, New Delhi.

Teguh Prasetyo, 2010, Hukum Pidana, Rajawali Pers, Jakarta.

Walter R. Borg and Meredith Damien Gall, 1989, Educational Research: An Introduction, Fifth Edition, Longman, New York.
Widodo, 2013, Hukum Pidana di Bidang Teknologi Informasi, Aswaja Pressindo, Yogyakarta.

\section{Jurnal}

Stephen N.Haynes; Leisen, Mary Beth; Blaine, Daniel D., 1997, Design Of Individualized Behavioral Treatment Programs Using Functional Analytic Clinical Case Models, Psychological Assessment, Volume 9 (4), Dec 1997. Widodo, 2007, Analisis Kriminologis tentang Penyebab Pelaku Kejahatan yang Berhubungan dengan Komputer di Indonesia (Studi di Unit V Infotek/ Cybercrime, Direktorat II Markas Besar Kepolisian Negara Republik 
Indonesia,"Jurnal Ilmiah Hukum dan Dinamika Masyarakat", Fakultas Hukum Universitas Tujuh belas Agustus Semarang, ISSN:0854-2031, TERAKREDITASI SK Dirjen Dikti No.55A/DIKTI/KEP/2006, Volume 4 No. 2, April 2007.

\section{Makalah}

Budi Yuliarno, Hubungan antara Kompetensi Sumberdaya Manusia dan Pembinaan Narapidana dengan Kinerja Lembaga Pemasyarakatan Kelas I Semarang, Tesis, Universitas Indonesia.

Soetandyo Wignjosoebroto, 2005, Hukum

dan Metode-metode Kajiannya, Makalah

Widodo dan Wiwik Utami, 2008, Pidana

Kerja Sosial dan Pidana Pengawasan sebagai Alternatif Pengganti Pidana Penjara bagi Pelaku Tindak Pidana Cybercrime (Studi di Daerah Hukum Pengadilan Tinggi Yogyakarta), Laporan Penelitian Fundnamental Tahun I.

Widodo, 2009, Pidana Kerja Sosial dan PidanaPengawasansebagaiAlternatif Penggati Pidana Penjara bagi Pelaku Tindak Pidana Cybercrime (Studi di Daerah Hukum Pengadilan Tinggi Yogyakarta), Laporan Akhir Hasil Penelitian Fundamental.

\section{Peraturan Perundang-undangan}

Undang-undang Republik Indonesia No. 12 Tahun 1995 tentang Pemasyarakatan

Keputusan Menteri Pendidikan Nasional Republik Indonesia Nomor 045/U/2002 tentang Kurikulum Inti Pendidikan Tinggi.

\section{Surat Kabar}

R.M. Roy Suryo, 11 Juli 2000, Kejahatan Cyber Marak di Indonesia, Suara Pembaharuan.

\section{Naskah Internet}

Balitbang SDM Kominfo Adakan SertifikasiSDM TIK, https://www. kominfo.go.id.

Celia Copadocia Yangco, CommunityBased Treatment For Offenders In The Philippines: Old Concepts, New Approaches, Best Practices, http:// www.unafei.or.

Lisa L. Miller, Looking for Postmodernism in all the Wrong Places Implementing a New Penology, bjc.oxfordjournals. org.

Nur Shobah, Aplikasi Andragogi dalam Pembelajaran pendidikan Non Formal, Pemerhati Pendidikan Orang Dewasa dan Pamong Belajar BPKB Sulteng, http://kurtekdik06.blogspot. com.

Pusbin KPK Beri Pelatihan Tukang Kepada Narapidana, www.pu.go.id. 
Some Leading Phases of The Evolution of

Modern Penology, archive.org/stream/ jstor.

\section{Laporan Hasil Penelitian}

Azriadi, Pelaksanaan Pembinaan

Narapidana Residivis Berdasarkan

Prinsip Pemasyarakatan di

Lembaga Pemasyarakatan Kelas II

A Biaro, (Tinjauan Mengenai Prinsip

Pemasyarakatan Tentang Perlindungan

Negara), Program Pascasarjana Ilmu

Hukum Universitas Andalas Padang, 2011.

Hamaria Mendrofa Simatupang, dan Irmawati, Dinamika Faktor-faktor
Psikososial pada Residivis Remaja Pria (Studi Kasus Residivis Remaja Pria di LAPAS Anak Tanjung Gusta Medan), Program Studi Psikologi Fakultas Kedokteran Universitas Sumatra Utara.

Mulyasa, 2005, Pengembangan Model Andragogi bagi Pembinaan dan pembimbingan Narapidana Perempuan di Lembaga Pemasyarakatan (Studi Terfokus pada Pendidikan Keagamaan (Islam) di Lembaga Pemasyarakatan Kelas IIA Bandung), Program Pascasarjana Universitas Pendidikan Indonesia (UPI), Bandung. 


\section{PETUNJUK PENULISAN JURNAL ARENA HUKUM}

\section{Pendahuluan}

- Jurnal Arena Hukum merupakan jurnal ilmiah yang terbit tiga kali edisi dalam satu tahun, yakni edisi Bulan April, Agustus dan Desember.

- Jurnal Arena Hukum adalah sarana untuk menyebarluaskan gagasan dan media komunikasi serta mengembangkan ide teoritis maupun praktis dalam pengembangan ilmu hukum yang merupakan hasil pemikiran dan penelitian para akademisi maupun praktisi hukum.

\section{Bentuk Naskah}

1. Naskah yang diterima adalah naskah yang belum pernah dipublikasikan sebelumnya. Jika naskah ternyata terbukti telah dipublikasikan, maka resiko hukum ditanggung oleh penulis dan akan mendapatkan sanksi dari Jurnal Arena Hukum.

2. Naskah ditulis dalam Bahasa Indonesia atau Bahasa Inggris.

3. Naskah dapat berupa hasil suatu penelitian (research paper) atau naskah ulasan (pemikiran) di bidang ilmu hukum, dengan sistematika sebagai berikut:

a. Naskah Hasil Penelitian, terdiri dari:

- Abstrak dan Kata Kunci (Memuat Tujuan, Metode dan Hasil Penelitian)

- Latar Belakang (Berisi Latar Belakang, Metode Penelitian dan Permasalahan)

- Pembahasan (uraian tentang permasalahan)

- Simpulan (memuat jawaban singkat permasalahan)

b. Naskah Ulasan, terdiri dari:

- Abstrak dan Kata Kunci (Memuat Tujuan dan Hasil Pemikiran)

- Latar Belakang (Berisi Latar Belakang dan Permasalahan)

- Pembahasan (uraian tentang permasalahan)

- Simpulan (memuat jawaban singkat permasalahan).

4. Di dalam naskah, penulisan istilah bahasa asing dicetak miring.

5. Penulisan paragraf dalam naskah menggunakan 5 ketukan.

\section{Prosedur Pengiriman Naskah}

1. Penulis mengirimkan naskah dalam bentuk soft copy / file melalui email arenahukum@ ub.ac.id atau arenahukum@yahoo.com atau arenahukum@gmail.com serta mengirimkan hard copy ke alamat redaksi.

2. Penulis yang telah mengirimkan naskah akan menerima tanda terima telah diterimanya naskah. 
3. Catatan: Naskah yang diterima tidak otomatis akan dimuat, karena akan melewati proses review dari dewan redaksi.

4. Penulis melampirkan surat PERNYATAAN KEASLIAN TULISAN bermaterai Rp. 6.000,00 yang dapat diunduh di laman http://hukum.ub.ac.id/penelitian-dan-publikasi/ publikasi/jurnal-arena-hukum/

\section{Format Naskah}

1. Format penulisan mempergunakan format satu kolom. Naskah setiap halaman diberi nomor berurutan, jumlah halaman 20 - 25 lembar (tidak termasuk daftar pustaka).

2. Naskah diketik pada kertas ukuran A4 (210 x $297 \mathrm{~mm})$ dengan jarak antar baris 1,5 spasi.

3. Naskah diketik dengan mempergunakan jenis huruf Times New Roman dengan ketentuan sebagai berikut:

- Judul naskah : 13 font, Kapital, Huruf Tebal

- Nama penulis : 12 font, huruf tebal

- Keterangan lembaga, alamat, email, telepon: 12 font

- Abstrak dan kata kunci: 12 font, huruf tebal, isi abstrak tidak perlu huruf tebal.

- Isi naskah : 12 font

- footnote : 10 font

- Daftar Pustaka : 13 font, Isi daftar Pustaka 12 font

- Letak Penomoran halaman: untuk halaman satu diletakkan dibawah tengah, untuk selanjutnya di pojok kanan atas.

4. Judul: Maksimal terdiri dari 12 kata untuk naskah Bahasa Indonesia dan 10 kata untuk naskah Bahasa Inggris.

5. Nama Penulis: Tidak disingkat, tanpa gelar, huruf tebal

6. Alamat Lengkap: Alamat lengkap instansi tempat penulis bekerja disertakan kode pos, nomor telepon dan fax, serta alamat email.

7. Abstrak dan Kata Kunci:

- Abstrak ditulis dalam 2 bahasa, Bahasa Inggris dan Bahasa Indonesia, disertai kata kunci (keyword) 3 - 5 kata kunci.

- Abstrak harus memuat Tujuan, Metode, dan Hasil Penelitian serta lengkap menggambarkan esensi isi keseluruhan tulisan untuk naskah penelitian, sedangkan untuk naskah ulasan tidak menggunakan metode.

- Abstrak terdiri dari 150 - 250 kata

- Abstrak ditulis satu spasi dan dalam satu paragraf. 
8. Latar Belakang:

- Penulisan judul tebal.

- Berisi tentang latar belakang, permasalahan dan metode penelitian untuk naskah penelitian, sedangkan untuk naskah ulasan tidak menggunakan metode.

- Berpola deduktif (umum-khusus)

9. Pembahasan: uraian tentang permasalahan

10. Simpulan: memuat jawaban singkat permasalahan

11. DAFTAR PUSTAKA:

a. Penulisan Daftar Pustaka disusun alfabetis.

b. Untuk penulisan nama penulis Indonesia dan atau penulis asing tidak dibalik.

c. Penulisan Judul tebal.

d. Dilarang menggunakan blog.

e. Daftar pustaka yang menggunakan E-book dan hard book harus ada nama pengarang dan penerbit.

f. Publisitas penyusunan daftar pustaka sebagai berikut:

- Buku

Bagir Manan, 1992, Dasar-dasar Perundang-undangan Indonesia, IND-HILL. CO, Jakarta.

- Jurnal

Moh. Fadli, 2011, Program Legislasi Nasional (Prolegnas): Ketersiapan Data dan Optimalisasi Kinerja DPR, Jurnal konstitusi, Volume IV No. 1, Juni 2011, PPK Fakultas Hukum Universitas Brawijaya, Malang.

- Makalah

Arsip dan Dokumentasi, 2011, Risalah Rapat Panitia Khusus (Pansus) Rancangan Undang-Undang tentang Pembentukan Peraturan Perundang-undangan tanggal 23 Februari 2011, Dewan Perwakilan Rakyat Republik Indonesia, Jakarta.

- Peraturan Perundang-undangan

Undang-undang Republik Indonesia Nomor 12 Tahun 2011 tentang Pembentukan Peraturan Perundang-undangan.

- Surat Kabar Tanpa Penulis

Kompas, 11 Agustus 2003, Aborsi di Tengah Polarisasi "Pro Life"_"Pro Choice". 
- Surat Kabar Dengan Penulis

Tim KPAI, 16 Juli 2009, Indonesia Negara Terbanyak Memidanan Anak, Kompas.

- Naskah Internet

DC. Kennedy, In Search of Balance Between Police Power and Privacy in The Cybercrime Treaty, The Richmond Journal Law and Technology, http:// www.richmond.jlt.html/185.

- Kamus

J. C. T. Simorangkir, dkk., 2006, Kamus Hukum, Cetakan Ke-10, Sinar Grafika, Jakarta.

12. Diutamakan dalam naskah dicantumkan TABEL atau GAMBAR atau BAGAN ALUR atau DIAGRAM

- Contoh Format Tabel:

Tabel 2.3. Presentase Tamu Domestik dan Tamu Asing yang Datang

\begin{tabular}{|c|l|r|r|}
\hline No & \multicolumn{1}{|c|}{ Bulan } & Tamu Domestik & Tamu Asing \\
\hline 1 & Januari & 86 & 14 \\
\hline 2 & Pebruari & 81 & 19 \\
\hline 3 & Maret & 80 & 20 \\
\hline
\end{tabular}

Sumber: Data Primer, diolah, 2007

- Contoh Format Gambar

Gambar 1. Ilustrasi Pasal 18 (4) UU 32/2004

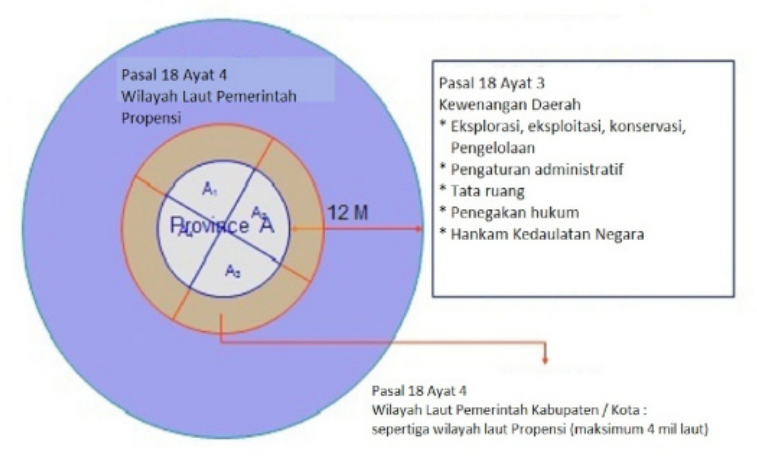

Sumber: Data Sekunder, diolah, 2007

Catatan:

1. Untuk penelitian hukum empiris, sumber menggunakan Data Sekunder

2. Untuk Penelitian hukum normatif:

1. Sumber dari Perundang-undangan:

Bahan Hukum Primer

2. Sumber dari Buku: Bahan Hukum Sekunder 
13. Setiap kutipan langsung dalam naskah harus diberi tanda petik 2 (")

14. Footnote:

Contoh penulisan footnote sebagai berikut:

- Buku

Bagir Manan, Dasar-dasar Perundang-undangan Indonesia, IND-HILL.CO, Jakarta, 1992, hlm. 3 .

C. De Rover, To Serve and To Protect: Acuan Universal Penegakan HAM, RajaGrafindo Persada, Jakarta, 2000, page 51.

- Buku karya terjemahan

Paul Scholten, De Structuur Dere Rechtswetenschap (Struktur Ilmu Hukum), Terjemahan oleh Arief Sidharta, Alumni, Bandung, 2011, hlm. 7.

- Buku yang berisi kumpulan naskah

Mahmod Thoha (Ed), Dampak Persetujuan Putaran Uruguay-GATT Terhadap Industri Kecil, UI Press, Jakarta, 1998, hlm. 89.

- Skripsi, tesis atau disertasi

Jazim Hamidi, Makna dan Kedudukan Hukum Naskah Proklamasi 17 Agustus 1945 dalam Sistem Ketatanegaraan Republik Indonesia, Disertasi Program Doktor Ilmu Hukum pada Fakultas Hukum Universitas Padjadjaran, 2005, Tidak dipublikasikan, hlm. 2.

- Artikel dalam buku kumpulan artikel

Moh Fadli, Non Delegation Doctrine dan Peraturan Delegasi di Indonesia, dalam Susi Dwi Harijanti (Eds), Negara Hukum yang Berkeadilan Kumpulan Pemikiran dalam Rangka Purnabakti Prof. Dr. H. Bagir Manan, Pusat Studi Kebijakan Negara Fakultas Hukum Universitas Padjadjaran (PSKN FH UNPAD), Bandung, 2011, hlm. 33.

- Artikel dalam jurnal

Moh. Fadli, Program Legislasi Nasional (Prolegnas): Ketersiapan Data dan Optimalisasi Kinerja DPR, Jurnal Konstitusi, Volume IV No.1, Juni 2011, PPK Fakultas Hukum Universitas Brawijaya, Malang, 2011, hlm. 20.

- Artikel dalam majalah atau surat kabar

K. Bartens, 11 Agustus 2003, Aborsi di Tengah Polarisasi "Pro Life"-“Pro Choice", Kompas, hlm. 89.

- Artikel dalam majalah atau surat kabar tanpa penulis Jawa Pos, 22 April 1995, Wanita Kelas Bawah Lebih Mandiri, hlm. 4. 


\section{- Makalah}

Ni'matul Huda, Penulisan Laporan Penelitian untuk Jurnal, makalah disajikan dalam

Lokakarya Penelitian Tingkat Dasar Bagi Dosen PTN dan PTS di Malang Angkatan XIV, Pusat Penelitian IKIP Malang, Malang, 12 Juli 2004, hlm. 53.

- Artikel internet

Ali Safaat, Penafsiran Konstitusi, http://safaat.lecture.ub.ac.id/files/2011/11/ Penafsiran-Konstitusi.pdf, diakses 3 Februari 2013 pukul 09.00 WIB.

DC. Kennedy, In Search of Balance Between Police Power and Privacy in The Cybercrime Treaty, The Richmond Journal Law and Technology, http://www. richmond.jlt.html/185.htm, diakses 12 Januari 2003 pukul 09.00 WIB.

- Dokumen resmi pemerintah

Arsip dan Dokumentasi, Risalah Rapat Panitia Khusus (Pansus) Rancangan Undangundang tentang Pembentukan Peraturan Perundang-undangan tanggal 23 Februari 2011, Jakarta, Dewan Perwakilan Rakyat Republik Indonesia, 2011, hlm. 7.

Pusat Pembinaan dan Pengembangan Bahasa, Pedoman Penulisan Laporan Penelitian, Jakarta, Departemen Pendidikan dan Kebudayaan, 1978, hlm. 88.

- Peraturan Perundang-undangan

Pasal 5 Undang-undang Nomor 12 Tahun 2011 tentang Pembentukan Peraturan Perundang-undangan.

- Hasil Wawancara

Wawancara dengan Aipda Aji Lukmansyah, S.H., Anggota Satreskrim Polres Malang Kota, 10 Nopember 2014.

- Singkatan dalam Footnote

1. Ibid, kependekan dari ibidem yang berarti 'di tempat yang sama dan belum diselingi dengan kutipan lain'.

2. Op.cit., singkatan dari opere citato, artinya 'dalam karangan yang telah disebut dan diselingi dengan sumber lain'.

3. Loc.cit, kependekan dari loco citato, artinya 'di tempat yang telah disebut'. loc.cit digunakan jika kita menunjuk ke halaman yang sama dari suatu sumber yang telah disebut.

Contoh Penulisannya:

Ibid., hlm. 80 .

Ibid.

Hesti Armiwulan Sochmawardiah, Op.cit., hlm. 62.

Hesti Armiwulan Sochmawardiah, Loc.cit., hlm. 62. 


\section{Penilaian Kelayakan Jurnal}

1. Setiap naskah yang memenuhi standar format penulisan sebagaimana ditentukan oleh Dewan Penyunting akan direview secara substansi oleh Mitra Bestari sesuai dengan bidang keahliannya.

2. Penulis wajib memperbaiki naskah sesuai saran dari dewan penyunting dan catatan Mitra Bestari dalam waktu 7 (tujuh) hari, sedangkan naskah yang ditolak akan dikembalikan kepada penulis disertai alasan penolakan.

3. Penentuan layak atau tidaknya naskah dimuat ditetapkan oleh Tim Jurnal Arena Hukum melalui Mitra Bestari, yang kemudian akan disampaikan kepada penulis. 


\title{
Panduan Untuk Penulis Jurnal ARENA HUKUM
}

\author{
JUDUL TIDAK BOLEH MELEBIHI 12 KATA UNTUK ARTIKEL \\ BAHASA INDONESIA, 10 KATA UNTUK \\ ARTIKEL BAHASA INGGRIS \\ (Times New Roman 13, Bold, Center, 1 spasi, UPPERCASE)
}

\author{
Nama Penulis (Times New Roman 13, Bold, Center)
}

Nama Lembaga

Alamat Lembaga

Email: Email penulis

(Times New Roman 12, Center, 1 spasi)

\begin{abstract}
Times New Roman 12, bold, italic, 1 spasi)
Abstract bahasa inggris harus dicetak miring. Abstract memuat tujuan, metode dan hasil penelitian untuk naskah yang dibuat berdasarkan hasil penelitian, sedangkan naskah ulasan tidak menggunakan metode. Abstract terdiri dari 150-250 kata. Abstract tidak boleh terjemahan dari google translate. Abstract ditulis menggunakan 1 spasi. Abstract bahasa inggris harus dicetak miring. Abstract memuat tujuan, metode dan hasil penelitian untuk naskah yang dibuat berdasarkan hasil penelitian, sedangkan naskah ulasan tidak menggunakan metode. Abstract terdiri dari 150 - 250 kata. Abstract tidak boleh terjemahan dari google translate. Abstract ditulis menggunakan 1 spasi. Abstract bahasa inggris harus dicetak miring. Abstract memuat tujuan, metode dan hasil penelitian untuk naskah yang dibuat berdasarkan hasil penelitian, sedangkan naskah ulasan tidak menggunakan metode. Abstract terdiri dari 150 - 250 kata. Abstract tidak boleh terjemahan dari google translate. Abstract ditulis menggunakan 1 spasi. Abstract bahasa inggris harus dicetak miring. Abstract memuat tujuan, metode dan hasil penelitian untuk naskah yang dibuat berdasarkan hasil penelitian, sedangkan naskah ulasan tidak menggunakan metode. Abstract terdiri dari 150 - 250 kata. Abstract tidak boleh terjemahan dari google translate. Abstract ditulis menggunakan 1 spasi. (Times New Roman 12, italic, 1 spasi)
\end{abstract}

Key words: keyword 1, keyword 2, keyword 3

\begin{abstract}
Abstrak (Times New Roman 12, Bold, 1 spasi)
Abstrak bahasa inggris harus dicetak miring. Abstrak memuat tujuan, metode dan hasil penelitian untuk naskah yang dibuat berdasarkan hasil penelitian, sedangkan naskah ulasan tidak menggunakan metode. Abstrak terdiri dari 150 - 250 kata. Abstrak tidak boleh terjemahan dari google translate. Abstrak ditulis menggunakan 1 spasi. Abstrak bahasa inggris harus dicetak miring. Abstrak memuat tujuan, metode dan hasil penelitian untuk naskah yang dibuat berdasarkan hasil penelitian, sedangkan naskah ulasan tidak menggunakan metode. Abstrak terdiri dari 150 - $250 \mathrm{kata}$. Abstrak tidak boleh terjemahan dari google translate. Abstrak ditulis menggunakan 1 spasi. Abstrak bahasa inggris harus dicetak miring. Abstrak memuat tujuan, metode dan hasil penelitian untuk naskah yang dibuat berdasarkan hasil penelitian, sedangkan
\end{abstract}


naskah ulasan tidak menggunakan metode. Abstrak terdiri dari 150 - 250 kata. Abstrak tidak boleh terjemahan dari google translate. Abstrak ditulis menggunakan 1 spasi. Abstrak bahasa inggris harus dicetak miring. Abstrak memuat tujuan, metode dan hasil penelitian untuk naskah yang dibuat berdasarkan hasil penelitian, sedangkan naskah ulasan tidak menggunakan metode. Abstrak terdiri dari 150 - 250 kata. Abstrak tidak boleh terjemahan dari google translate. Abstrak ditulis menggunakan 1 spasi. (Times New Roman 12, 1 spasi)

Kata kunci: kata kunci 1, kata kunci 2, kata kunci 3

\section{Latar Belakang (Times New Roman 12, Bold)}

Pada Latar Belakang merupakan bab pertama dari naskah yang harus memuat permasalahan dan metode penelitian. Latar belakang merupakan uraian informasi sehubungan dengan timbulnya masalah penelitian. Latar belakang juga memuat ketertarikan penulis pada suatu pokok bahasan yang ditunjang dengan data awal serta uraian singkat teori yang relevan dengan pokok bahasan. Latar Belakang memuat permasalahan dan metode penelitian.

Contoh penulisan footnote buku ${ }^{1}$. Contoh penulisan footnote Skripsi, Tesis dan Disertasi ${ }^{2}$. Contoh penulisan footnote wawancara ${ }^{3}$. Contoh penulisan footnote Peraturan Perundangundangan ${ }^{4}$. Contoh penulisan footnote naskah internet ${ }^{5}$. Contoh Penulisan footnote artikel dalam surat kabar ${ }^{6}$. Contoh penulisan footnote Artikel dalam majalah atau surat kabar tanpa penulis ${ }^{7}$.

Naskah jurnal diketik dengan huruf Times New Roman 12, 1 1/2 spasi, justify (rata kanan kiri), di atas kertas A4 dengan batas margin atas $3 \mathrm{~cm}$, bawah $3 \mathrm{~cm}$, kanan $3 \mathrm{~cm}$, kiri $4 \mathrm{~cm}$, minimal 20 - 25 halaman belum termasuk daftar pustaka.

\section{Pembahasan}

Pembahasan memuat uraian tentang hasil penelitian atau hasil kajian teoritis / konseptual untuk naskah ulasan. Apabila terdapat rincian sesuai dengan permasalahan dan menggunakan sub bab, maka bisa dituliskan sesuai dengan penulisan sub bab di bawah ini.

1 Nama (tanpa dibalik), Judul Sumber (Bold), Nama Kota, Penerbit, tahun penerbit, hlm. buku. (Times New Roman 10).

Bagir Manan, Dasar-dasar Perundang-undangan Indonesia, IND-HILL.CO, Jakarta, 1992, hlm. 3.

C. De Rover, To Serve and To Protect: Acuan Universal Penegakan HAM, RajaGrafindo Persada, Jakarta, 2000 , page 51.

2 Jazim Hamidi, Makna dan Kedudukan Hukum Naskah Proklamasi 17 Agustus 1945 dalam Sistem Ketatanegaraan Republik Indonesia, Disertasi Program Doktor Ilmu Hukum pada Fakultas Hukum Universitas Padjadjaran, 2005, Tidak dipublikasikan, hlm. 2.

3 Wawancara dengan Aipda Aji Lukmansyah, S.H., Anggota Satreskrim Polres Malang Kota, 10 Nopember 2014.

4 Pasal 5 Undang-undang Nomor 12 Tahun 2011 tentang Pembentukan Peraturan Perundang-undangan.

5 Ali Safaat, Penafsiran Konstitusi, http://safaat.lecture.ub.ac.id/files/2011/11/Penafsiran-Konstitusi.pdf, diakses 3 Februari 2013 pukul 09.00 WIB.

6 K. Bartens, 11 Agustus 2003, Aborsi di Tengah Polarisasi "Pro Life"-"Pro Choice", Kompas, hlm. 89.

7 Jawa Pos, 22 April 1995, Wanita Kelas Bawah Lebih Mandiri, hlm. 4. 


\section{A. Sub Bab (Times New Roman, Bold, Huruf Besar Setiap Awal Kata)}

Sub Bab Sub Bab Sub Bab Sub Bab Sub Bab Sub Bab Sub Bab Sub Bab Sub Bab Sub Bab Sub Bab Sub Bab Sub Bab Sub Bab Sub Bab Sub Bab Sub Bab Sub Bab Sub Bab Sub Bab Sub Bab Sub Bab Sub Bab Sub Bab Sub Bab Sub Bab Sub Bab Sub Bab Sub Bab Sub Bab.

Sub Bab Sub Bab Sub Bab Sub Bab Sub Bab Sub Bab Sub Bab Sub Bab Sub Bab Sub Bab Sub Bab Sub Bab Sub Bab Sub Bab Sub Bab Sub Bab Sub Bab Sub Bab Sub Bab Sub Bab Sub Bab Sub Bab Sub Bab Sub Bab Sub Bab Sub Bab Sub Bab Sub Bab Sub Bab Sub Bab.

\section{Sub sub bab (Times New Roman, Bold, Huruf Besar Hanya di Awal Kalimat)}

Sub Sub Bab Sub Sub Bab Sub Sub Bab Sub Sub Bab Sub Sub Bab Sub Sub Bab Sub Sub Bab Sub Sub Bab Sub Sub Bab Sub Sub Bab Sub Sub Bab Sub Sub Bab Sub Sub Bab Sub Sub Bab Sub Sub Bab Sub Sub Bab Sub Sub Bab Sub Sub Bab Sub Sub Bab Sub Sub Bab Sub Sub Bab Sub Sub Bab Sub Sub Bab Sub Sub Bab Sub Sub Bab.

Sub Sub Bab Sub Sub Bab Sub Sub Bab Sub Sub Bab Sub Sub Bab Sub Sub Bab Sub Sub Bab Sub Sub Bab Sub Sub Bab Sub Sub Bab Sub Sub Bab Sub Sub Bab Sub Sub Bab Sub Sub Bab Sub Sub Bab Sub Sub Bab Sub Sub Bab Sub Sub Bab Sub Sub Bab Sub Sub Bab Sub Sub Bab Sub Sub Bab Sub Sub Bab Sub Sub Bab Sub Sub Bab.

\section{Sub sub bab (Times New Roman, Bold, Huruf Besar Hanya di Awal Kalimat)}

Sub Sub Bab Sub Sub Bab Sub Sub Bab Sub Sub Bab Sub Sub Bab Sub Sub Bab Sub Sub Bab Sub Sub Bab Sub Sub Bab Sub Sub Bab Sub Sub Bab Sub Sub Bab Sub Sub Bab Sub Sub Bab Sub Sub Bab Sub Sub Bab Sub Sub Bab Sub Sub Bab Sub Sub Bab Sub Sub Bab Sub Sub Bab Sub Sub Bab Sub Sub Bab Sub Sub Bab Sub Sub Bab.

\section{B. Sub Bab (Times New Roman, Bold, Huruf Besar Setiap Awal Kata)}

Sub Bab Sub Bab Sub Bab Sub Bab Sub Bab Sub Bab Sub Bab Sub Bab Sub Bab Sub Bab Sub Bab Sub Bab Sub Bab Sub Bab Sub Bab Sub Bab Sub Bab Sub Bab Sub Bab Sub Bab Sub Bab Sub Bab Sub Bab Sub Bab Sub Bab Sub Bab Sub Bab Sub Bab Sub Bab Sub Bab.

Sub Bab Sub Bab Sub Bab Sub Bab Sub Bab Sub Bab Sub Bab Sub Bab Sub Bab Sub Bab Sub Bab Sub Bab Sub Bab Sub Bab Sub Bab Sub Bab Sub Bab Sub Bab Sub Bab Sub Bab Sub Bab Sub Bab Sub Bab Sub Bab Sub Bab Sub Bab Sub Bab Sub Bab Sub Bab Sub Bab. 


\section{Simpulan}

Simpulan memuat jawaban singkat dari permasalahan. Simpulan boleh dibuat paragraf atau boleh dibuat secara penomoran.

1. Berisi hasil dari permasalahan. Berisi hasil dari permasalahan. Berisi hasil dari permasalahan. Berisi hasil dari permasalahan. Berisi hasil dari permasalahan. Berisi hasil dari permasalahan. Berisi hasil dari permasalahan. Berisi hasil dari permasalahan. Berisi hasil dari permasalahan. Berisi hasil dari permasalahan. Berisi hasil dari permasalahan. Berisi hasil dari permasalahan. Berisi hasil dari permasalahan. Berisi hasil dari permasalahan. Berisi hasil dari permasalahan.

2. Berisi hasil dari permasalahan. Berisi hasil dari permasalahan. Berisi hasil dari permasalahan. Berisi hasil dari permasalahan. Berisi hasil dari permasalahan. Berisi hasil dari permasalahan. Berisi hasil dari permasalahan. Berisi hasil dari permasalahan. Berisi hasil dari permasalahan. Berisi hasil dari permasalahan. Berisi hasil dari permasalahan. Berisi hasil dari permasalahan. Berisi hasil dari permasalahan. Berisi hasil dari permasalahan. Berisi hasil dari permasalahan.

3. Berisi hasil dari permasalahan. Berisi hasil dari permasalahan. Berisi hasil dari permasalahan. Berisi hasil dari permasalahan. Berisi hasil dari permasalahan. Berisi hasil dari permasalahan. Berisi hasil dari permasalahan. Berisi hasil dari permasalahan. Berisi hasil dari permasalahan. Berisi hasil dari permasalahan.

Apabila dalam naskah disajikan Tabel, penulisan dan pengutipannya adalah sebagai berikut:

Tabel 2.3. Presentase Tamu Domestik dan Tamu Asing yang Datang (Times New Roman 12, Bold, Rata Kiri, 1 spasi)

\begin{tabular}{|c|l|r|r|}
\hline No & Bulan & Tamu Domestik & Tamu Asing \\
\hline 1 & Januari & 86 & 14 \\
\hline 2 & Pebruari & 81 & 19 \\
\hline 3 & Maret & 80 & 20 \\
\hline
\end{tabular}

Sumber: $\quad$ Data Primer, diolah, 2007 (Times New Roman 12, Bold, Rata Kiri, 1 spasi) 
Apabila dalam naskah disajikan Tabel, penulisan dan pengutipannya adalah sebagai berikut:

Gambar 1. Ilustrasi Pasal 18 (4) UU 32/2004 (Times New Roman 12, Bold, Rata Kiri, 1 spasi)

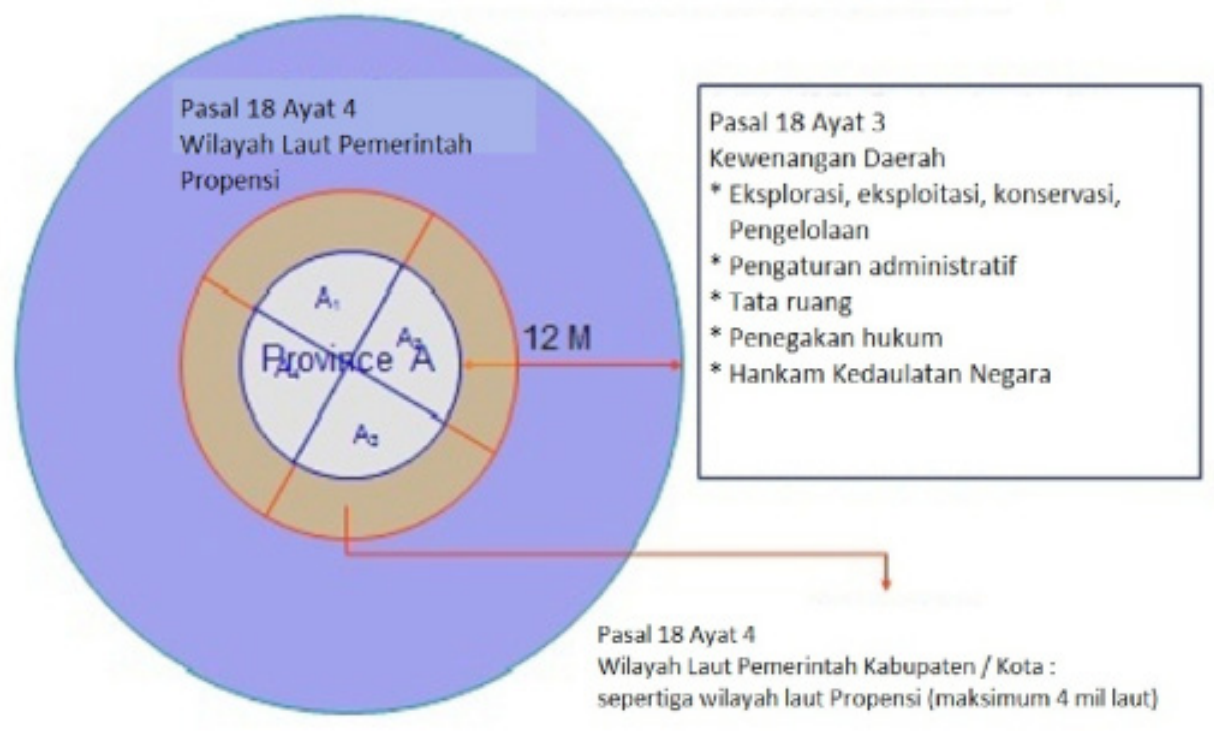

Sumber: Data Sekunder, diolah, 2007 (Times New Roman 12, Bold, Rata Kiri, 1 spasi)

Catatan:

1. Untuk penelitian hukum empiris, sumber menggunakan Data Sekunder

2. Untuk Penelitian hukum normatif:

a. Sumber dari Perundang-undangan : Bahan Hukum Primer

b. Sumber dari Buku : Bahan Hukum Sekunder 


\section{DAFTAR PUSTAKA \\ (Times New Roman 13, center, bold)}

\section{Syarat:}

a. Penulisan Daftar Pustaka disusun alfabetis dan urut berdasarkan bentuk publisitasnya.

b. Untuk penulisan nama penulis Indonesia dan atau penulis asing tidak dibalik.

c. Penulisan Judul tebal.

d. Dilarang menggunakan blog.

e. Daftar pustaka yang menggunakan E-book dan hard book harus ada nama pengarang dan penerbit.

f. Publisitas penyusunan daftar pustaka sebagai berikut:

\section{Buku}

Bagir Manan, 1992, Dasar-dasar Perundang-undangan Indonesia, IND-HILL.CO, Jakarta. Jurnal

Moh. Fadli, 2011, Program Legislasi Nasional (Prolegnas): Ketersiapan Data dan Optimalisasi Kinerja DPR, Jurnal konstitusi, Volume IV No. 1, Juni 2011, PPK Fakultas Hukum Universitas Brawijaya, Malang.

\section{Makalah}

Arsip dan Dokumentasi, 2011, Risalah Rapat Panitia Khusus (Pansus) Rancangan Undangundang tentang Pembentukan Peraturan Perundang-undangan tanggal 23 Februari 2011, Dewan Perwakilan Rakyat Republik Indonesia, Jakarta.

\section{Peraturan Perundang-undangan}

Undang-undang Republik Indonesia Nomor 12 Tahun 2011 tentang Pembentukan Peraturan Perundang-undangan.

\section{Surat Kabar Tanpa Penulis}

Kompas, 11 Agustus 2003, Aborsi di Tengah Polarisasi "Pro Life"-“Pro Choice".

\section{Surat Kabar Dengan Penulis}

Tim KPAI, 16 Juli 2009, Indonesia Negara Terbanyak Memidanan Anak, Kompas.

\section{Naskah Internet}

DC. Kennedy, In Search of Balance Between Police Power and Privacy in The Cybercrime

Treaty, The Richmond Journal Law and Technology, http://www.richmond.jlt.html/185.

\section{Kamus}

J. C. T. Simorangkir, dkk., 2006, Kamus Hukum, Cetakan Ke-10, Sinar Grafika, Jakarta. 


\title{
Susunan Pengelola
}

Penanggung Jawab

Ketua Dewan Penyunting

Wakil Ketua Dewan Penyunting

Pelaksana Tata Usaha

Anggota Dewan Penyunting

Editor Pelaksana
: Dekan Fakultas Hukum Universitas Brawijaya

: Dr. Nurini Aprilianda, SH., M.Hum.

: Mufatikhatul Farikhah, SH., MH.

: Ratna Sri Hartatik, S.Pd.

: 1. Dr. Moh. Fadli, SH., MH.

2. Dr. Lucky Endrawati, SH., MH.

3. Sucipto, SH., MH.

4. Imam Kuswahyono, SH., M.Hum.

5. Hanif Nur Widhiyanti, SH., M.Hum.

6. Aan Eko Widiarto, SH., M.Hum.

7. Dhia Al Uyun, SH., MH.

8. Budi Santoso, SH., LL.M.

9. Faizin Sulistyo, SH., LL.M.

10. Reka Dewantara, SH., MH.

: 1. Yuliati, SH., LL.M.

2. Prischa Listiningrum, $\mathrm{SH}$.

3. Nabilla Desyalika Putri, SH.

\section{Mitra Bebestari}

Mitra Bestari adalah para ahli di bidang hukum yang berasal dari Universitas di Indonesia dan / atau dari luar negeri, yang mempunyai kompetensi untuk menelaah naskah sesuai bidang ilmu masing-masing.

\author{
Alamat Redaksi \& Tata Usaha \\ JURNAL ARENA HUKUM \\ Jl. Mayjen Haryono 169 Malang 65145 \\ Lantai V Gedung A Fakultas Hukum Universitas Brawijaya \\ Telp. (0341) 553898; Fax. (0341) 566505 \\ Email: arenahukum@ub.ac.id / arenah ukum@yahoo.com / \\ arenahukum@gmail.com \\ Website: arenahukum@ub.ac.id
}

CP: 1. Mufatikhatul Farikhah, SH., MH.; No. Telp. 081252306499

2. Ratna Sri Hartatik, S.Pd.; No. Telp. 085655576573

Catatan: Penulis tidak dipungut biaya apapun. 


\section{FORMULIR BERLANGGANAN}

Mohon dicatat sebagai pelanggan Jurnal Arena Hukum Fakultas Hukum Universitas Brawijaya:

Nama

Alamat

Nomor telp./HP. :

gunting dan dikirimkan ke alamat Redaksi Arena Hukum atau fax ke (0341) 566505.......

\section{BERITA PENGIRIMAN UANG LANGGANAN}

Dengan ini saya kirimkan uang sebesar:

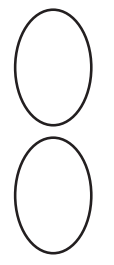

Rp. 50.000,00 x .... eksemplar, untuk langganan mulai nomor ... s/d nomor ... (belum termasuk ongkos kirim)

Uang tersebut telah saya kirim melalui:

Bank BNI Kantor Cabang Pembantu Universitas Brawijaya

Rekening Nomor 039649440 a.n. Rektor UB q.q Penmas Non Utul

\section{Catatan:}

1. Pengiriman jurnal kepada pelanggan, baru dilayani setelah ada bukti pengiriman uang penggantian ongkos cetak dan uang ongkos kirim melaui transfer bank.

2. Harga/penggantian ongkos cetak per eksemplar Rp. 50.000,00

3. Ongkos kirim berdasar domisili pelanggan dihitung dengan menggunakan tarif Jasa Pos.

4. Jika pelanggan pindah alamat domisili/kantor dimohon memberitahukan kepada Tata usaha Arena Hukum.

\section{FORMULIR INI BOLEH DIFOTOKOPI}

